\title{
Leadership, quality of worklife, job satisfaction and organizational citizenship behavior in PT. Pertamina
}

\author{
Imam Moestain ${ }^{a^{*}}$, Hamidah ${ }^{\mathrm{a}}$ and Kadir ${ }^{\mathrm{a}}$
}

${ }^{a}$ Universitas Negeri Jakarta, Indonesia

\begin{tabular}{l}
\hline C H R O N I C L E \\
\hline Article history: \\
Received: October 26, 2019 \\
Received in revised format: No- \\
vember 272019 \\
Accepted: November 27, 2019 \\
Available online: \\
November 27, 2019 \\
\hline Keywords: \\
Leadership \\
Quality of worklife \\
Job satisfaction \\
Organizational citizenship behav- \\
ior \\
\end{tabular}
A B S T R A C T

\begin{abstract}
Organizational citizenship behavior (OCB) is a form of positive, constructive and meaningful social behavior that helps the tasks given by the leadership become lighter if there are workers with high OCB and that the consequences will increase productivity and success which can be seen as a factor that contributes to the work of the company. This study aims to examine the leadership and quality of worklife on organizational citizenship behavior mediated by job satisfaction at PT. Pertamina (Persero). The sampling technique used by researchers is proportional random sampling. In this study, there are 359 employees working for this firm where 217 people are the employees of PT. Pertamina (Persero) MOR III Jakarta and 142 are working for MOR V Surabaya. The sample of respondents used in this study are 189 people. The procedure used in testing, data processing and model development is a structural equation model. Data are analyzed using SMART-PLS tools. The results indicate that there is a positive direct effect of leadership on job satisfaction, there is a positive direct effect of quality of worklife on job satisfaction, there is a positive influence of leadership on OCB, there is a positive direct effect of quality of worklife on $\mathrm{OCB}$, there is a positive direct effect on job satisfaction on OCB, there is a positive indirect effect between leadership and OCB through job satisfaction, and there is a positive indirect effect between quality of worklife and OCB through job satisfaction.
\end{abstract}

(C) 2020 by the authors; licensee Growing Science, Canada

\section{Introduction}

The goals of any organization is normally determined by the behavior of human resources in that organization. Every employee has duties and responsibilities aimed at achieving the goals of implementing functions in the organization. Every employee in the organization is required to have organizational citizenship behavior so that the functions of the organization are run as expected and the goals that have been made can be achieved. Organizational citizenship behavior (OCB) at PT. Pertamina (Persero) MOR III Jakarta and MOR V Surabaya, is still not optimal with an indication that there are still many permanent workers who work home on time, arrive late and attendance is still low. This can be seen from employee absenteeism data in all MOR III Jakarta and Mor V Surabaya departments. There are still many absences and late work. Leadership at PT.Pertamina (Persero) MOR III Jakarta and MOR V Surabaya, seems still not well received by every employee, from the results of a brief interview of 30 employees and the results of the questionnaire we found there are still some employees who do not comply with all decisions issued by the leadership, are reluctant to pay attention to the new policies issued by the leadership and some employees have not felt the leader communicates within the company using a family approach. Quality of work life is a major problem that deserves the attention of the organization because it is considered capable of increasing employee participation in the organization. By conducting a brief interview and seeing the results of the questionnaire we realize that majority of employees at PT. Pertamina (Persero) MOR III Jakarta and MOR V Surabaya, still do not provide a comfortable workspace to carry out their duties, are not optimal in anticipating health for employees, and are lacking care about improving the completeness of the workplace.

\footnotetext{
* Corresponding author.

E-mail address: sekretaris@pertaminafoundation.org (I. Moestain) 
Factors that can affect employee job satisfaction basically can be practically divided into two parts, intrinsic factors and extrinsic factors. Through a brief interview to 30 existing employees and seeing the results of a questionnaire about job satisfaction, the majority of employees of PT. Pertamina (Persero) still feel compelled to work on any work given to themselves, some still feel that company regulations are not optimal in facilitating employee needs, employees feel the company is less concerned with the work situation, and the benefits given by the company to each employee are still lacking in value and not appropriate. From the description above, it can be concluded that every company that exists really needs the support of competent human resources or workers who have a loyal attitude towards their organization so that the company's goals can be achieved. To achieve the desired level of organizational citizenship behavior, every organization must pay attention to leadership, quality of work life, and job satisfaction of each employee. Based on this phenomenon, the researcher is interested in making a dissertation entitled Leadership, Quality of Worklife, Job Satisfaction, and OCB at PT. Pertamina (Persero).

\section{Literature review}

\subsection{Organizational Citizenship Behavior}

Kinickiand and Kreitner (2010) suggested that OCB is an employee behavior that exceeds work role requirements and consists of employee behavior that is beyond the call of duty. Examples include such gestures as constructive statements about the department, expressions of personal interest in the work of others, suggestions for improvement, training new people, respect for the spirit as well as the letter of house keeping rules, care of organizational property, and punctuality and attendance well beyond the standard or enforceable level. Robbins and Judge (2013) clarifies the OCB concept that when someone is in a good mood, he/she tends to be able to do more than the organization or company's duties. Thus, OCB is a behavior and attitudes that benefit the organization that cannot be grown on the basis of the obligation of formal roles or contract forms. Podsakoff et al. (2000), mentioned 7 dimensions of OCB, namely (1) helping behavior, (2) sportsmanship, (3) organizational loyalty, (4) organizational compliance, (5) individual initiative, (6) civic virtue, and (7) self-development. Meanwhile according to Kumar and Shah (2015), OCB dimensions are altruism, courtesy, civic virtue, sportsmanship, conscientiousness. OCB has seven dimensions as follows: First the nature of helping, someone who has a good OCB will like to help others even though there is no appreciation for it. Both sportsmanlike attitudes, individuals who are said to have good OCB, will have a sporty nature such as not complaining when treated unfavorably by their colleagues and still doing their jobs well. It could also be that the individual will sacrifice his/her personal desires for the sake of his/her work. Third, loyalty or loyalty, with a good OCB, a person will have a high level of loyalty, for example an individual will remain loyal to his/her organization even though the organization is experiencing difficult conditions. Fourth adherence to the organization, Individuals will comply even with very strict organizational regulations. The five individual initiatives, individuals will have more initiative, for example someone will ask if he/she does not understand his/her work, or another example is someone will do his/her work and not wait to be instructed first. Sixth civic virtue / citizenship, this dimension relates to citizenship in which the individual will be more responsive to the things that are done by the government, so he/she will inform about the changes that occur and inform the organization. Seventh self-development, voluntary actions that can improve abilities, skills and knowledge. Based on the description above it can be synthesized that OCB is a form of employee behavior that has a voluntary willingness to carry out tasks, obligations and is not a forced action and various other things that are needed outside of these duties and obligations in order to provide more effort in promoting the interests of the company to achieve its objectives in accordance with the scope of PT.Pertamina (Persero) MOR Jakarta and Surabaya are seen in indicators: 1) altruism (caring), 2) civic virtue (virtue), 3) conscientiousness (sincerity), 4) courtesy (courtesy), 5. sportsmanship, (sportsmanship).

\subsection{Leadership}

Colquitt et al. (2015) define leadership as follows: "leadership is the use of power and influence to direct the activities of followers toward goal achievement". According to George and Jones (2012) leadership is defined as "leadership as the exercise of influence by one member of a group or organization over other members to help the group or organization achieve its goals". According to Robbins and Timothy (2014) transformational leadership consists of two combined words, namely, leadership which has meaning as someone who directs and coordinates who must be able to turn an idea into reality or change a concept into real action. Robbins and Timothy (2014) proposed 4 indicators of transformational leadership known as the concept of "4I" which suggest to transformational leaders to be able to garner trust, respect and admiration from their followers as for the indicators of transformational leadership as follows:

1. Idealized influence, the leader must be a good example, which can be followed by his employees, so that it will produce respect and trust in the leader.

2. Inspirational motivation, leaders must be able to provide motivation, and clear targets to be achieved by their employees.

3. Intellectual simulation, leaders must be able to stimulate their employees to come up with new ideas and ideas, leaders must also let their employees become problem solvers and provide new innovations under their guidance.

4. Individualized consideration, leaders must pay attention, listen to complaints, and understand the needs of their employees.

All of these dimensions, if implemented properly, will help in maximizing the role of leaders in the company. From some of the opinions above it can be synthesized that leadership is a kind of leadership that is able to guide and encourage subordinates 
to believe in themselves, understand the abilities, have high motivation and be able to complete duties properly and produce high performance and work performance to encourage achievement of organizational goals, with indicators: 1). ideal influence (idealized influence), 2). inspirational motivation (inspirational motivation), 3). intellectual simulation (intellectual simulation), 4) individual consideration (individualized consideration).

\subsection{Quality of Worklife}

According to Griffin and Moorhead (2014), "the quality of work life (QWL) is the extent to which workers can satisfy the important needs of people despite their experience in the organization". In line with what Bateman and Thomas (2007) pointed out, the general purpose of the quality of work life is to meet employee's needs, therefore QWL has eight categories, namely: 1) the remuneration is appropriate and adequate, 2) a safe and healthy environment, 3) work to develop human capabilities, 4) the opportunity for growth and personal security, 5) the social environment that shapes personal identity, freedom of suspicion, 6) constitutionalism, or the right to privacy, and the process of mutual disagreements, 7) the role of and, 8) the organization acts socially responsible. According to Erdem (2014) there was no general consensus that could be agreed upon. Erdem (2014) developed several QWL indicators, namely: total area of life, safe and healthy work conditions, improving the work capacity, social integration, democratic environment, fair and appropriate compensation. Total area of life, safe and healthy working conditions, increased work capacity, social integration, democratic environment, fair and appropriate compensation. Based on a theoretical study of the quality of work life, it can be synthesized that the quality of work life is the perception that employees have of a situation which is based on the fulfillment of the degree of conformity of welfare expected by employees ideally related to their works. If employees feel the quality of work life in the company both will have a positive impact in efforts to achieve company goals. Measurement of quality of work life, with indicators: 1). total area of work life, 2). safe and healthy work conditions, 3). improving the workplace capacity, 4) social integration, 5). democratic environment, 6). fair and appropriate compensation.

\subsection{Job Satisfaction}

According to Robbins and Judge (2013) "Job satisfaction is a positive feeling about a job resulting from an evaluation of its characteristics is clearly broad". The impact of satisfied and dissatisfied shows in one theoretical model-the exit-voice- loyalty-neglect framework-is helpful in understanding the consequences of dissatisfactions. The framework four responses, which differ along two dimensions: constructive / destructive and active / passive. According to Colquitt et al (2015) "Job satisfaction is defined as a pleasurable emotional state resulting from the appraisal of one's job or job experience". According to James et al. (2012), "Job satisfaction is an attitude that individuals have about their Jobs. It results from their perceptions of their jobs, based on factors of the work environment, such as the supervisor style, policies and procedures, work group affiliations, working conditions, and fringe benefits". James et al. (2012) indicate a satisfaction work is: 1) The supervisor style, 2). Policies and procedures, 3). Work group affiliation, 4). Working conditions, 5). fringe benefits. Based on the definition of the concepts that have been described can be synthesized work satisfaction is the employee's perception of feelings of pleasure and displeasure and how well their work can provide things that are considered important about their work based on work environment factors, with indicators: 1). The supervisor style, 2). Policies and procedures, 3). Work group affiliation, 4). Working conditions, 5). fringe benefits.

\section{Method}

In this study the research method used is a quantitative approach through survey methods. Analysis of the data used is to use the method of structural equation modeling, using SMART-PLS statistical computation tools. The way to collect the data needed in this study was carried out through questionnaires, interviews and tests that had been prepared in advance. This study will examine the relationship between variables and measure the influence of each variable with each other, while the variables to be examined, namely: leadership (X1), quality of worklife (X2), job satisfaction (X3) and organizational citizenship behavior. The following is a research instrument grid and the relationship between the research variables can be described in the research constellation as follows:

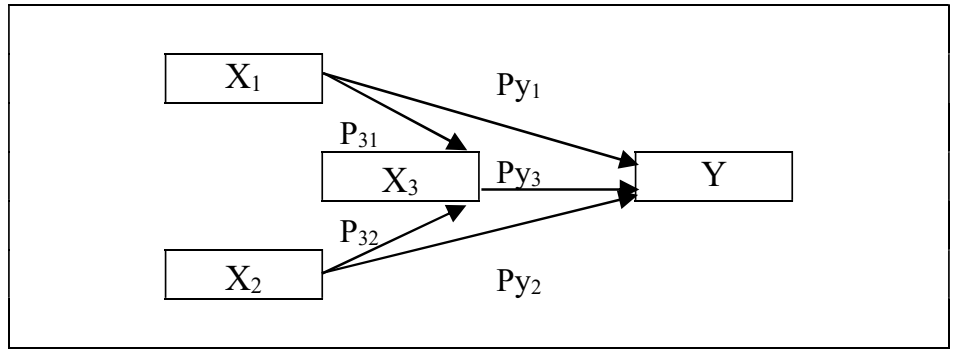

Fig. 1. The proposed method

Based on the descriptions in the conceptual description, relevant research results and theoretical framework, the following research hypotheses can be formulated: 
1. Leadership (leadership) has a positive effect on organizational citizenship behavior.

2. Quality of work life (quality of work life) has a positive effect on organizational citizenship behavior.

3. Job satisfaction has a positive effect on organizational citizenship behavior.

4. Leadership (leadership) has a positive effect on employee satisfaction.

5. Quality of work life (quality of work life) has a positive effect on employee satisfaction.

6. Leadership (leadership) influences organizational citizenship behavior mediated by job satisfaction.

7. Quality of work life influences organizational citizenship behavior mediated by job satisfaction.

Population is a generalization area consisting of objects or subjects that have certain quantities or characteristics determined by researchers to be studied and then draw conclusions. Affordable population in this study are permanent workers who work at the head office of PT. Pertamina (Persero) MOR III Jakarta numbering: 217 people and PT. Pertamina (Persero) MOR V Surabaya numbered 142 people, with a total of 359 people. The target variable studied is organizational citizenship behavior (OCB) permanent workers who work at the headquarters of PT. Pertamina (Persero) Marketing Operation Region (MOR) III Jakarta and PT. Pertamina (Persero) Marketing Operation Region (MOR) V Surabaya. The number of samples is determined using the formula Taro Yamane or Slovin in Riadi (2018), as follows:

$$
n=\frac{N}{N \cdot d^{2}+1}
$$

where $n, N$ are sample size and population number, respectively. In addition, $d$ is the precision set, which is 0.05 when the level of confidence is $95 \%$. In our study we have, $359 /\left(359 \times 0.05^{2}+1\right)=189$. Based on Eq. (1) with an error rate of $5 \%$ of the population, then the sample taken amounted to 189 people, with details of 114 people MOR III Jakarta and 75 people MOR V Surabaya. The sampling technique uses proportional random sampling technique. This technique is chosen based on the consideration that members of the population have the same opportunity to be chosen.

\section{The results}

In a study conducted, researchers distributed 189 questionnaires to employees of PT. Pertamina (Pesrero) MOR III Jakarta and MOR V Surabaya. The profiles of respondents in this study are differed by age, gender, job experience and educational background. Fig. 1 shows the results of the profile of PT. Pertamina (Pesero) MOR III Jakarta and MOR V Surabaya:

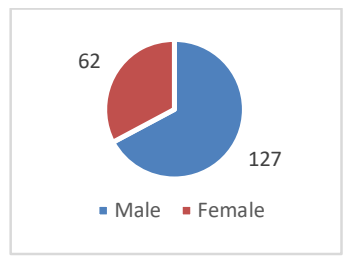

Gender

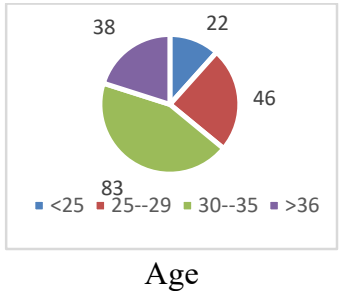

Fig. 2. Personal characteristics of the participants

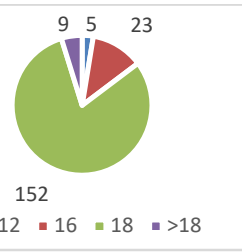

Years of education

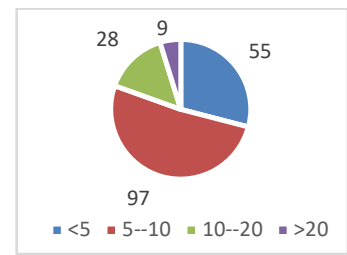

Job experience

According to Fig. 1, it can be explained that there were more respondents were male, namely 127 people with a percentage of $60.19 \%$, while 62 respondents were female with a percentage of $32.80 \%$. Also, it was found that respondents with age $\leq 25$ years amounted to 22 people with a percentage of $11.64 \%$, respondents with ages $25-29$ years totaling 46 people with a percentage of $24.33 \%$, respondents with ages $30-35$ years totaling 83 people with a percentage of $43.91 \%$, and respondents with age $\geq 36$ years amounted to 38 people with a percentage of $20.10 \%$.

\subsection{Organizational Citizenship Behavior (Y)}

The variable score of OCB (Y) was obtained from 189 respondents by filling out a questionnaire which totaled 35 statements. The summary of descriptive data for the OCB (Y) variable is shown in Table 1. The variable score for organizational citizenship behavior was obtained from 189 respondents by filling out a questionnaire of 35 statements. The scoring is done by using a Likert scale for each statement item. Based on the calculation data summarized in Table 1 the highest score (maximum) was 175 and the lowest score (minimum) was 94, the average score was 135, the score that often appears (mode) was 149, the middle score (median) was 137, the standard deviation (standard deviation) was 19.18 and variance was 367.83 . By using the Sturgess rule, the number of interval classes is 9 and the length of the interval is 10 so that a list of frequency distributions of organizational citizenship behavior scores can be made as shown in Table 2 as follows.

Table 1

Summary Description of Variable Data Organizational Citizenship Behavior (Y)

\begin{tabular}{clccccccc}
\hline No. & Description & Score & No. & Description & Score & No. & Description \\
\hline 1 & Number of respondents & 189 & 6 & Range of scores & 81 & 11 & Median \\
2 & Number of statement & 35 & 7 & Interval Amount & 9 & 12 & Variance \\
3 & Number of Variable & 25.541 & 8 & Class Intervals & 10 & 13 & Standard deviation & 19,18 \\
4 & Highest score & 175 & 9 & Average score & 135 & \\
5 & Lowest score & 94 & 10 & Mode & 149 & \\
\hline
\end{tabular}


Table 2

Frequency Distribution of Organizational Citizenship Behavior (Y) Score

\begin{tabular}{|c|c|c|c|c|c|c|c|c|}
\hline \multirow[t]{2}{*}{ No. } & \multicolumn{3}{|c|}{ Class Intervals } & \multicolumn{2}{|c|}{ Limit } & \multicolumn{3}{|c|}{ Frequency } \\
\hline & & & & Lower & Upper & Absolute & Relatively(\%) & Cumulative (\%) \\
\hline 1 & 94 & - & 103 & 93.5 & 103.5 & 10 & 5.29 & 5.29 \\
\hline 2 & 104 & - & 113 & 103.5 & 113.5 & 22 & 11.64 & 16.93 \\
\hline 3 & 114 & - & 123 & 113.5 & 123.5 & 18 & 9.52 & 26.46 \\
\hline 4 & 124 & - & 133 & 123.5 & 133.5 & 29 & 15.34 & 41.80 \\
\hline 5 & 134 & - & 143 & 133.5 & 143.5 & 47 & 24.87 & 66.67 \\
\hline 6 & 144 & - & 153 & 143.5 & 153.5 & 34 & 17.99 & 84.66 \\
\hline 7 & 154 & - & 163 & 153.5 & 163.5 & 15 & 7.94 & 92.59 \\
\hline 8 & 164 & - & 173 & 163.5 & 173.5 & 12 & 6.35 & 98.94 \\
\hline 9 & 174 & - & 183 & 173.5 & 183.5 & 2 & 1.06 & 100.00 \\
\hline & & & & & & 189 & $100 \%$ & \\
\hline
\end{tabular}

\subsection{Leadership (X1)}

The leadership variable score (X1) was obtained from 189 respondents by filling out questionnaires totaling 28 statements. The summary of descriptive data for the leadership variable (X1) is shown in Table 3 as follows,

Table 3

Summary of Data Description of Leadership Variables (X1)

\begin{tabular}{clcrlcccc}
\hline No. & Description & Score & No. & Description & Score & No. & Description & Score \\
\hline 1 & Number of respondents & 189 & 6 & Range of scores & 56 & 11 & 111 \\
2 & Number of statement & 28 & 7 & Interval Amount & 9 & 12 & Variance \\
3 & Number of Variable & 21.025 & 8 & Class Intervals & 7 & 13 & Standard deviation & 14.17 \\
4 & Highest score & 140 & 9 & Average score & 111.24 & & \\
5 & Lowest score & 84 & 10 & Mode & 124 & & \\
\hline
\end{tabular}

The leadership variable score was obtained from 189 respondents by filling out a questionnaire of 28 statements. Scoring is done by using a Likert scale for each statement item. Based on the calculation data summarized in Table 3 the highest score (maximum) was 140 and the lowest score (minimum) was 84, the average score was 111.24, the score that often appears (mode) was 124, the middle score (median) was 111, the standard deviation (standard deviation) was 14.18 and the variance was 201.17. Using the Sturgess rule, the number of interval classes was 9 and the length of the interval was 7 so that a frequency distribution list of leadership scores can be made as in Table 4 as follows,

Table 4

Leadership Score Frequency Distribution (X1)

\begin{tabular}{|c|c|c|c|c|c|c|c|c|}
\hline \multirow[t]{2}{*}{ No. } & \multicolumn{3}{|c|}{ Class Intervals } & \multicolumn{2}{|c|}{ Limit } & \multicolumn{3}{|c|}{ Frequency } \\
\hline & & & & Under & On & Absolute & Relatively(\%) & Cumulative $(\%)$ \\
\hline 1 & 84 & - & 90 & 83.5 & 90.5 & 18 & 9.52 & 9.52 \\
\hline 2 & 91 & - & 97 & 90.5 & 97.5 & 16 & 8.47 & 17.99 \\
\hline 4 & 105 & - & 111 & 104.5 & 111.5 & 38 & 20.11 & 51.85 \\
\hline 5 & 112 & - & 118 & 111.5 & 118.5 & 30 & 15.87 & 67.72 \\
\hline 6 & 119 & - & 125 & 118.5 & 125.5 & 31 & 16.40 & 84.13 \\
\hline 7 & 126 & - & 132 & 125.5 & 132.5 & 11 & 5.82 & 89.95 \\
\hline 8 & 133 & - & 139 & 132.5 & 139.5 & 17 & 8.99 & 98.94 \\
\hline 9 & 140 & - & 146 & 139.5 & 146.5 & 2 & 1.06 & 100.00 \\
\hline & & & & & & 189 & $100 \%$ & \\
\hline
\end{tabular}

\subsection{Quality of Work Life $\left(X_{2}\right)$}

The variable score of quality of work life (X2) was obtained from 189 respondents by filling out a questionnaire totaling 42 statements. The summary of descriptive data for the variable quality of work life (X2) as shown in Table 5:

\section{Table 5}

Summary of Quality of Work Life (X2) Variable Data Description

\begin{tabular}{clcrlcccc}
\hline No. & Description & Score & No. & Description & Score & No. & Description & Score \\
\hline 1 & Number of respondents & 189 & 6 & Range of scores & 94 & 11 & 169 \\
2 & Number of statement & 42 & 7 & Interval Amount & 9 & 12 & Variance \\
3 & Number of Variable & 30.838 & 8 & Class Intervals & 11 & 13 & Standard deviation \\
4 & Highest score & 210 & 9 & Average score & 163 & & \\
5 & Lowest score & 116 & 10 & Mode & 185 & \\
\hline
\end{tabular}

Quality of work life variable scores were obtained from 189 respondents by completing a questionnaire of 42 statements. Scoring is done by using a Likert scale for each statement item. Based on the calculation data summarized in Table 5 the highest score (maximum) was 210 and the lowest score (minimum) was 116, the average score was 163 , the score that often 
appears (mode) was 185, the middle score (median) was 169, the standard deviation (standard deviation) was 24.5 and variance was 600.78. By using the Sturgess rule, the number of interval classes is 9 and the length of the interval is 11 so that a frequency distribution list of quality of work life scores can be made as shown in Table 6:

Table 6

Frequency Distribution of Quality of Work Life Scores (X2)

\begin{tabular}{|c|c|c|c|c|c|c|c|c|}
\hline \multirow[t]{2}{*}{ No. } & \multicolumn{3}{|c|}{ Class Intervals } & \multicolumn{2}{|c|}{ Limit } & \multicolumn{3}{|c|}{ Frequency } \\
\hline & & & & Lower & Upper & Absolute & Relatively(\%) & Cumulative (\%) \\
\hline 1 & 116 & - & 126 & 115.5 & 126.5 & 19 & 10.05 & 10.05 \\
\hline 2 & 127 & - & 137 & 126.5 & 137.5 & 22 & 11.64 & 21.69 \\
\hline 3 & 138 & - & 148 & 137.5 & 148.5 & 18 & 9.52 & 31.22 \\
\hline 4 & 149 & - & 159 & 148.5 & 159.5 & 14 & 7.41 & 38.62 \\
\hline 5 & 160 & - & 170 & 159.5 & 170.5 & 30 & 15.87 & 54.50 \\
\hline 6 & 171 & - & 181 & 170.5 & 181.5 & 23 & 12.17 & 66.67 \\
\hline 7 & 182 & - & 192 & 181.5 & 192.5 & 49 & 25.93 & 92.59 \\
\hline 8 & 193 & - & 203 & 192.5 & 203.5 & 9 & 4.76 & 97.35 \\
\hline \multirow[t]{2}{*}{9} & 204 & - & 214 & 203.5 & 214.5 & 5 & 2.65 & 100.00 \\
\hline & & & & & & 189 & $100 \%$ & \\
\hline
\end{tabular}

\subsection{Job Satisfaction (X3)}

Job satisfaction variable score (X3) is obtained from 189 respondents by filling out a questionnaire totaling 34 statements. The summary of descriptive data for the job satisfaction variable (X3) is shown in Table 7 as follows,

Table 7

Summary of Job Satisfaction Variable Data Description (X3)

\begin{tabular}{clcclc}
\hline No. & Description & Score & No. & Description \\
\hline 1 & Number of respondents & 189 & 8 & Class Intervals \\
2 & Number of statement items & 34 & 9 & Average score \\
3 & Number of Variable Scores & 23.819 & 10 & Mode & 126 \\
4 & Highest score & 170 & 11 & Median \\
5 & Lowest score & 99 & 12 & Variance \\
6 & Range of scores & 71 & 13 & Standard deviation \\
7 & Interval Amount & 9 & & & 121 \\
\hline
\end{tabular}

Job satisfaction variable scores were obtained from 189 respondents by filling out a questionnaire totaling 34 statement items. Scoring is performed by using a Likert scale for each statement item. Based on the calculation data summarized in Table 7, the highest score (maximum) is 170 and the lowest score (minimum) is 99, the average score is 126 , the score that often appears (mode) is 130, the middle score (median) is 121, the standard deviation (standard deviation) is 18.81 and the variance is 353.97. Using the Sturgess rule, the number of interval classes is 9 and the length of the interval is 8 so that a frequency distribution list of job satisfaction scores can be made as in Table 8. In processing data, researchers used linear regression techniques that were tested with Partial Least Square (PLS) using SmartPLS software version 3.2.8.

Table 8

Frequency Distribution of Job Satisfaction Scores (X3)

\begin{tabular}{|c|c|c|c|c|c|c|c|c|}
\hline \multirow[t]{2}{*}{ No. } & \multicolumn{3}{|c|}{ Class Intervals } & \multicolumn{2}{|c|}{ Limit } & \multicolumn{3}{|c|}{ Frequency } \\
\hline & & & & Lower & Upper & Absolute & Relatively(\%) & Cumulative (\%) \\
\hline 1 & 99 & - & 106 & 98.5 & 106.5 & 38 & 20.11 & 20.11 \\
\hline 2 & 107 & - & 114 & 106.5 & 114.5 & 24 & 12.70 & 32.80 \\
\hline 4 & 123 & - & 130 & 122.5 & 130.5 & 16 & 8.47 & 60.32 \\
\hline 5 & 131 & - & 138 & 130.5 & 138.5 & 12 & 6.35 & 66.67 \\
\hline 6 & 139 & - & 146 & 138.5 & 146.5 & 36 & 19.05 & 85.71 \\
\hline 7 & 147 & - & 154 & 146.5 & 154.5 & 13 & 6.88 & 92.59 \\
\hline 8 & 155 & - & 162 & 154.5 & 162.5 & 7 & 3.70 & 96.30 \\
\hline \multirow[t]{2}{*}{9} & 163 & - & 170 & 162.5 & 170.5 & 7 & 3.70 & 100.00 \\
\hline & & & & & & 189 & $100 \%$ & \\
\hline
\end{tabular}

\subsection{Evaluate the Outer Model}

The goodness of fit test for the outer model in PLS consists of three tests, namely convergent validity, discriminant validity, and composite reliability testing.

\subsubsection{Convergent Validity}

The convergent validity value is the factorial loading value of the latent variable with its indicators. In the PLS model, meeting the convergence validity value can be said to be valid if the loading value is $0.5-0.6$. Convergent validity explains the ability 
of each indicator to explain the research variables studied. To find out whether or not latent indicators are valid, we look at the loading factor values. Variable indicator must be greater than 0.5. Table 9 demonstrates the results.

Table 9

Outer Loading Calculation Matrix

\begin{tabular}{|c|c|c|c|c|c|c|c|}
\hline Item & $\begin{array}{l}\text { Outer Load- } \\
\text { ing Mini- } \\
\text { mum }\end{array}$ & $\begin{array}{c}\text { Outer } \\
\text { Loading } \\
\text { Results }\end{array}$ & Information & Item & $\begin{array}{l}\text { Outer Loading } \\
\text { Minimum }\end{array}$ & $\begin{array}{l}\text { Outer Loading } \\
\text { Results }\end{array}$ & Information \\
\hline \multicolumn{4}{|c|}{ Organizational Citizenship Behavior (Y) } & \multicolumn{3}{|c|}{ Leadership (X1) } & \\
\hline 1 & 0.5 & 0.793 & Valid & 1 & 0.5 & 0.667 & Valid \\
\hline 2 & 0.5 & 0.869 & Valid & 2 & 0.5 & 0.648 & Valid \\
\hline 3 & 0.5 & 0.823 & Valid & 3 & 0.5 & 0.695 & Valid \\
\hline 4 & 0.5 & 0.657 & Valid & 4 & 0.5 & 0.652 & Valid \\
\hline 5 & 0.5 & 0.684 & Valid & 5 & 0.5 & 0.736 & Valid \\
\hline 6 & 0.5 & 0.755 & Valid & 6 & 0.5 & 0.815 & Valid \\
\hline 7 & 0.5 & 0.801 & Valid & 7 & 0.5 & 0.738 & Valid \\
\hline 8 & 0.5 & 0.669 & Valid & 8 & 0.5 & 0.837 & Valid \\
\hline 9 & 0.5 & 0.787 & Valid & 9 & 0.5 & 0.783 & Valid \\
\hline 10 & 0.5 & 0.693 & Valid & 10 & 0.5 & 0.79 & Valid \\
\hline 11 & 0.5 & 0.631 & Valid & 11 & 0.5 & 0.666 & Valid \\
\hline 12 & 0.5 & 0.663 & Valid & & & & \\
\hline \multicolumn{4}{|c|}{ Quality of Work Life (X2) } & \multicolumn{3}{|c|}{ Job Satisfaction (X3) } & \\
\hline 1 & 0.5 & 0.681 & Valid & 1 & 0.5 & 0.625 & Valid \\
\hline 2 & 0.5 & 0.724 & Valid & 2 & 0.5 & 0.764 & Valid \\
\hline 3 & 0.5 & 0.736 & Valid & 3 & 0.5 & 0.809 & Valid \\
\hline 4 & 0.5 & 0.747 & Valid & 4 & 0.5 & 0.651 & Valid \\
\hline 5 & 0.5 & 0.845 & Valid & 5 & 0.5 & 0.842 & Valid \\
\hline 6 & 0.5 & 0.787 & Valid & 6 & 0.5 & 0.717 & Valid \\
\hline 7 & 0.5 & 0.61 & Valid & 7 & 0.5 & 0.665 & Valid \\
\hline 8 & 0.5 & 0.791 & Valid & 8 & 0.5 & 0.747 & Valid \\
\hline 9 & 0.5 & 0.722 & Valid & 9 & 0.5 & 0.603 & Valid \\
\hline 10 & 0.5 & 0.75 & Valid & 10 & 0.5 & 0.653 & Valid \\
\hline 11 & 0.5 & 0.681 & Valid & 11 & 0.5 & 0.731 & Valid \\
\hline 12 & 0.5 & 0.648 & Valid & & & & \\
\hline 13 & 0.5 & 0.727 & Valid & & & & \\
\hline 14 & 0.5 & 0.637 & Valid & & & & \\
\hline 15 & 0.5 & 0.677 & Valid & & & & \\
\hline
\end{tabular}

Table 9 shows that all indicators are declared valid because it has a loading factor value above 0.5 . The biggest loading factor value for variable organizational citizenship behavior lies in indicator number 3 with a value of 0.861 while the lowest value lies in indicator number 1 with a value of 0.542 . In the leadership variable the highest loading factor value lies in indicator number 10 with a value of 0.830 . while the lowest value lies in indicator number 4 with a value of 0.602 . In the variable quality of work life, the highest value of loading factor lies in indicator number 5 with a value of 0.842 . while the lowest value lies in indicator number 7 with a value of 0.585 . In the job satisfaction, the highest loading factor value is indicator number 6 with a value of 0.828 . while the lowest value lies in indicator number 1 with a value of 0.614 .

\subsubsection{Discriminant Validity Test}

Discriminant validity test needs to be done to see the validity of indicators in measuring latent variables. An indicator is declared valid if it has the highest loading factor to the intended construct compared to the loading factor of the correlation of other latent indicators. Table 10 shows the results of cross loadings matrix for discriminating validity. The results of Table 10 indicate that there are no indicators that can predict variables other than the variables themselves. This can be seen from the highest loading factor of each indicator in the variable column to be measured. Thus, latent variables predict indicators in their blocks better than indicators in other blocks.

Another method for assessing discriminant validity is to look at the Average Variance Extracted (AVE) value, the value suggested as an initial research according to Riadi (2018) is above 0.5. Table 1 shows the AVE values in this study. 
Table 10

Cross Loading Calculation Matrix

\begin{tabular}{|c|c|c|c|c|c|c|c|c|c|}
\hline & 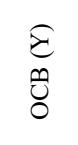 & 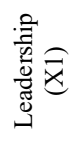 & 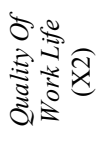 & 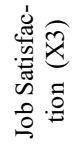 & & 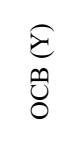 & 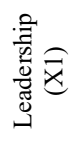 & 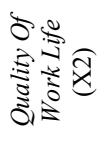 & 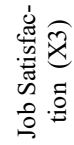 \\
\hline OCB1 & 0.793 & 0.603 & 0.407 & 0.488 & QWL3 & 0.442 & 0.334 & 0.736 & 0.508 \\
\hline OCB2 & 0.869 & 0.682 & 0.538 & 0.616 & QWL4 & 0.308 & 0.34 & 0.747 & 0.428 \\
\hline OCB3 & 0.823 & 0.591 & 0.484 & 0.518 & QWL5 & 0.336 & 0.276 & 0.845 & 0.477 \\
\hline OCB4 & 0.657 & 0.542 & 0.241 & 0.47 & QWL6 & 0.492 & 0.392 & 0.787 & 0.54 \\
\hline OCB5 & 0.684 & 0.561 & 0.436 & 0.409 & QWL7 & 0.263 & 0.089 & 0.61 & 0.366 \\
\hline OCB6 & 0.755 & 0.589 & 0.379 & 0.42 & QWL8 & 0.213 & 0.362 & 0.791 & 0.527 \\
\hline OCB7 & 0.801 & 0.63 & 0.417 & 0.528 & QWL9 & 0.334 & 0.39 & 0.722 & 0.508 \\
\hline OCB8 & 0.669 & 0.593 & 0.397 & 0.526 & QWL10 & 0.34 & 0.33 & 0.75 & 0.472 \\
\hline OCB9 & 0.787 & 0.678 & 0.46 & 0.583 & QWL11 & 0.276 & 0.442 & 0.681 & 0.371 \\
\hline OCB 10 & 0.693 & 0.58 & 0.42 & 0.58 & QWL12 & 0.392 & 0.308 & 0.648 & 0.479 \\
\hline OCB11 & 0.631 & 0.582 & 0.448 & 0.586 & QWL13 & 0.089 & 0.336 & 0.727 & 0.56 \\
\hline OCB12 & 0.663 & 0.604 & 0.415 & 0.512 & QWL14 & 0.362 & 0.492 & 0.637 & 0.491 \\
\hline LD1 & 0.61 & 0.667 & 0.382 & 0.486 & QWL15 & 0.39 & 0.263 & 0.677 & 0.331 \\
\hline LD2 & 0.564 & 0.648 & 0.403 & 0.453 & JS1 & 0.255 & 0.249 & 0.424 & 0.625 \\
\hline LD3 & 0.641 & 0.695 & 0.396 & 0.532 & JS2 & 0.573 & 0.572 & 0.441 & 0.764 \\
\hline LD4 & 0.617 & 0.652 & 0.451 & 0.474 & JS3 & 0.59 & 0.544 & 0.45 & 0.809 \\
\hline LD5 & 0.525 & 0.736 & 0.16 & 0.427 & JS4 & 0.384 & 0.373 & 0.402 & 0.651 \\
\hline LD6 & 0.662 & 0.815 & 0.366 & 0.476 & JS5 & 0.705 & 0.631 & 0.626 & 0.842 \\
\hline LD7 & 0.569 & 0.738 & 0.202 & 0.429 & JS6 & 0.562 & 0.578 & 0.375 & 0.717 \\
\hline LD8 & 0.675 & 0.837 & 0.38 & 0.552 & JS7 & 0.44 & 0.456 & 0.365 & 0.665 \\
\hline LD9 & 0.58 & 0.783 & 0.266 & 0.478 & JS8 & 0.545 & 0.473 & 0.458 & 0.747 \\
\hline LD10 & 0.672 & 0.79 & 0.451 & 0.621 & JS9 & 0.361 & 0.329 & 0.525 & 0.603 \\
\hline LD11 & 0.399 & 0.666 & 0.108 & 0.36 & JS10 & 0.337 & 0.321 & 0.541 & 0.653 \\
\hline QWL1 & 0.105 & 0.105 & 0.681 & 0.283 & JS11 & 0.592 & 0.518 & 0.406 & 0.731 \\
\hline QWL2 & 0.33 & 0.213 & 0.724 & 0.32 & & & & & \\
\hline
\end{tabular}

Table 11

Average Variance Extracted (AVE) Matrix

\begin{tabular}{lcc}
\hline \multicolumn{1}{c}{ Variable } & Average Variance Extracted (AVE) & \\
\hline Organizational Citizenship Behavior (Y) & 0.546 & Valid \\
Leadership (X1) & 0.537 & Valid \\
Quality of Work Life (X2) & 0.519 & Valid \\
Job Satisfaction (X3) & 0.509 & \\
\hline
\end{tabular}

According to the results of Table 11, it can be seen that all variables have AVE values exceeding 0.5 which can be interpreted that all variables are valid.

\section{Composite Reliability}

Reliability test on the outer model can be measured by two criteria, namely composite reliability or Cronbach alpha of the indicator block that measures the construct. The construct is declared reliable if the composite reliability value is above 0.70 . These values can be seen in the table and diagram below:

Table 12

Composite Reliability Matrix

\begin{tabular}{lcc}
\hline Variable & Composite Reliability & \\
\hline Organizational Citizenship Behavior (Y) & 0.935 & Information \\
Leadership (X1) & 0.927 & Valid \\
Quality of Work Life (X2) & 0.941 & Valid \\
Job Satisfaction (X3) & 0.919 & Valid \\
\hline
\end{tabular}

Based on Table 12, it can be seen that the composite reliability value of all latent variables is obtained above 0.7 which can be interpreted that all variables in this study meet the requirements and are reliable.

\section{Hypothesis Testing}

The statistical test conducted in this study was by a significance level of $5 \%$ and the decision criteria for $\mathrm{H}_{0}$ is rejected if the $\mathrm{p}$-value $\mathrm{i} \leq 5 \%$ or $\mathrm{t}$ statistic $>\mathrm{t}$ table (1.96). Table 13 shows the results of path coefficients and $\mathrm{t}$ test: 
Table 13

Path coefficient matrix and T test (Direct Effects)

\begin{tabular}{|c|c|c|c|c|c|}
\hline & Original Sample (O) & $\begin{array}{l}\text { Sample Mean } \\
(\mathrm{M})\end{array}$ & $\begin{array}{l}\text { Standard Deviation } \\
\text { (STDEV) }\end{array}$ & $\begin{array}{l}\text { T Statistics } \\
(|\mathrm{O} / \mathrm{STDEV}|)\end{array}$ & Sig. \\
\hline $\mathrm{LD}(\mathrm{X} 1) \rightarrow \mathrm{OCB}(\mathrm{Y})$ & 0.615 & 0.62 & 0.063 & 9.747 & 0.000 \\
\hline QWL $(\mathrm{X} 2) \rightarrow$ OCB $(\mathrm{Y})$ & 0.172 & 0.172 & 0.051 & 3.356 & 0.001 \\
\hline $\mathrm{JS}(\mathrm{X} 3) \rightarrow \mathrm{OCB}(\mathrm{Y})$ & 0.189 & 0.185 & 0.08 & 2.355 & 0.019 \\
\hline $\mathrm{LD}(\mathrm{X} 1) \rightarrow \mathrm{JS}(\mathrm{X} 3)$ & 0.473 & 0.471 & 0.048 & 9.820 & 0.000 \\
\hline QWL $(\mathrm{X} 2) \rightarrow \mathrm{JS}(\mathrm{X} 3)$ & 0.42 & 0.426 & 0.047 & 8.859 & 0.000 \\
\hline
\end{tabular}

Table 14

The results of Indirect Effects

\begin{tabular}{lcccr} 
& Original Sample $(\mathrm{O})$ & Sample Mean $(\mathrm{M})$ & Standard Deviation $(\mathrm{STDEV})$ & T Statistics $(|\mathrm{O} / \mathrm{STDEV}|)$ \\
\hline $\mathrm{KP}(\mathrm{X} 1) \rightarrow \mathrm{KK}(\mathrm{X} 3) \rightarrow$ OCB $(\mathrm{Y})$ & 0.09 & 0.086 & 0.036 & 2.469 \\
$\mathrm{QWL}(\mathrm{X} 2) \rightarrow \mathrm{KK}(\mathrm{X} 3) \rightarrow$ OCB $(\mathrm{Y})$ & 0.08 & 0.08 & 0.038 & 0.014 \\
\hline
\end{tabular}

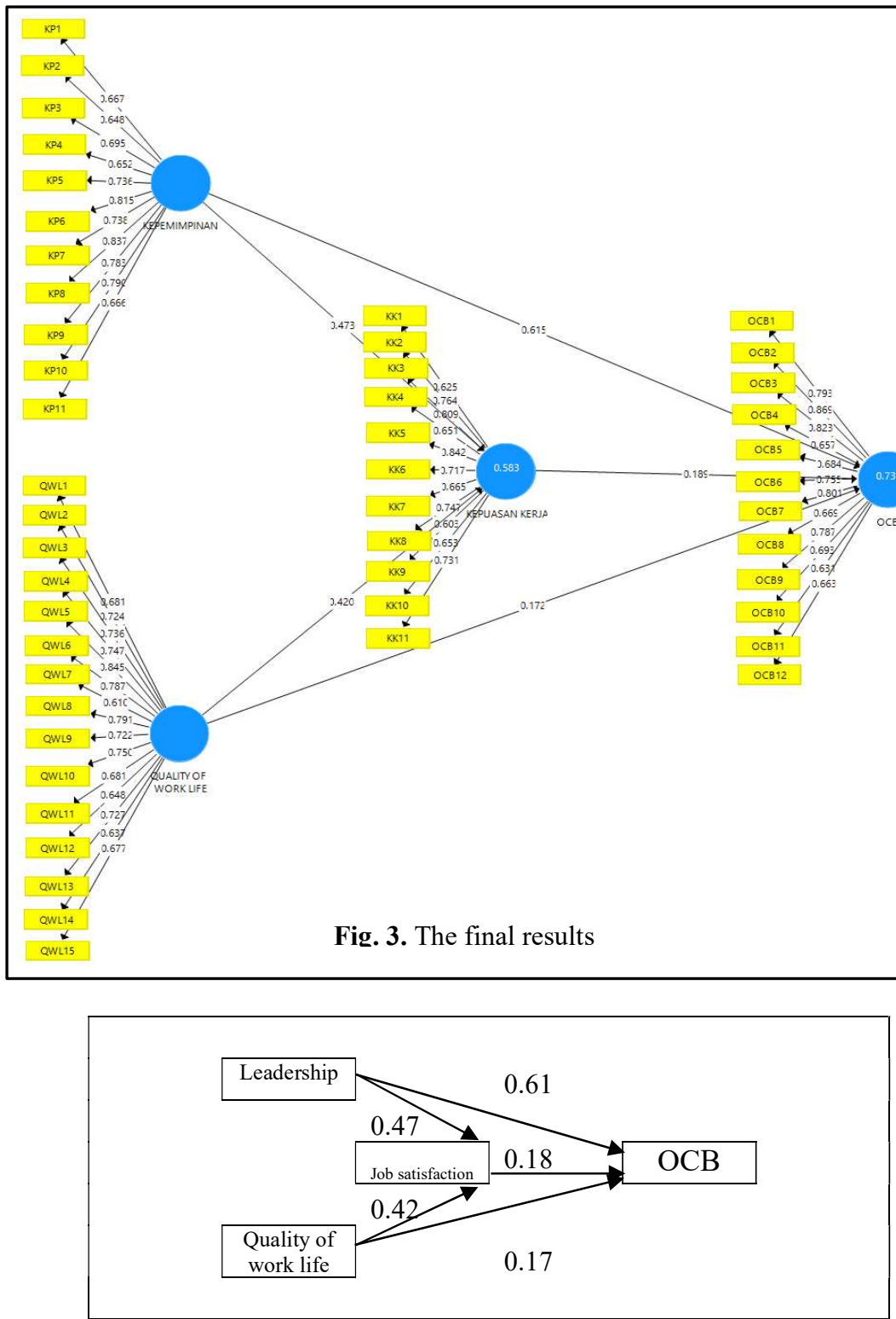

Fig. 4. The summary of the structural model

The results of the structural model analysis in Fig. 3 and Fig. 4 produce estimates of causal relationships between variables in the form of t-values and path coefficient values. The explanation is described as follows: 
Table 15

Causal Relations Between Variables

\begin{tabular}{|c|c|c|c|c|c|c|}
\hline No & Path & Path coefficient & t-value & t-table & Significance & Conclusion \\
\hline 1 & Leadership $\rightarrow$ OCB & 0,615 & 9,747 & 1,96 & Significant & $\begin{array}{l}\text { There is sufficient evidence that leadership has a pos- } \\
\text { itive effect on OCB }\end{array}$ \\
\hline 2 & $\begin{array}{l}\text { Quality of work life } \rightarrow \\
\text { OCB }\end{array}$ & 0,172 & 3,356 & 1,96 & Significant & $\begin{array}{l}\text { There is sufficient evidence that quality of work life } \\
\text { has a positive effect on OCB }\end{array}$ \\
\hline 3 & Job satisfaction $\rightarrow$ OCB & 0,189 & 2,355 & 1,96 & Significant & $\begin{array}{l}\text { There is sufficient evidence that job satisfaction has } \\
\text { a positive effect on OCB }\end{array}$ \\
\hline 4 & $\begin{array}{l}\text { Leadership } \rightarrow \text { Job satis- } \\
\text { faction }\end{array}$ & 0,473 & 9,820 & 1,96 & Significant & $\begin{array}{l}\text { There is sufficient evidence that leadership has a pos- } \\
\text { itive effect on job satisfaction }\end{array}$ \\
\hline 5 & $\begin{array}{l}\text { Quality of work life } \\
\rightarrow \text { Job satisfaction }\end{array}$ & 0,420 & 8,859 & 1,96 & Significant & $\begin{array}{l}\text { There is sufficient evidence that quality of work life } \\
\text { has a positive effect on job satisfaction }\end{array}$ \\
\hline 6 & $\begin{array}{l}\text { Leadership } \rightarrow \text { Job satis- } \\
\text { faction } \rightarrow \text { OCB }\end{array}$ & 0,090 & 2,469 & 1,96 & Significant & $\begin{array}{l}\text { There is sufficient evidence that leadership has an in- } \\
\text { directly positive effect on OCB through job satisfac- } \\
\text { tion }\end{array}$ \\
\hline 7 & $\begin{array}{l}\text { Quality of work life } \\
\rightarrow \text { Job satisfaction } \rightarrow \\
\text { OCB }\end{array}$ & 0,080 & 2,068 & 1,96 & Significant & $\begin{array}{l}\text { There is sufficient evidence that quality of work life } \\
\text { has an indirect positive effect on OCB through job } \\
\text { satisfaction }\end{array}$ \\
\hline
\end{tabular}

\section{Discussion}

\subsection{Effect of leadership on organization citizenship behavior}

The influence of leadership on organizational citizenship behavior is positive at 0.612 and significant at 9.051> 1.96. Thus, it can be concluded that leadership has a direct positive effect on organizational citizenship behavior by $61.2 \%$. This explains the value of construct reliability (composite reliability matrix) and matrix average variance extracted leadership variable (X1) and organizational citizenship behavior (Y), where the value of construct reliability (matrix composite reliability) leadership is $0.927>0.70$ and it can be concluded to be significant and for the value Average variance of extracted leadership is $0.518>$ 0.50 and it can be concluded significant. While the value of construct reliability (composite reliability matrix) organizational citizenship behavior is equal to $0.932>0.70$ and it can be concluded significant and for the average variance extracted leadership value is $0.518>0.50$ and it can be concluded significant. The results of this study reinforce the theory put forward by Yang and Wei (2018) which shows that leadership ethics significantly influences OCB. Further research by Meri Prasetyawati (2015) reveales that leadership style was positively and significantly correlated with OCB. While Kartini's research (2017) shows that there is a positive and significant influence of leadership style on OCB.

\subsection{Effect of quality of work life on organizational citizenship behavior}

The influence of quality of work life on organizational citizenship behavior is positive at 0.176 and significant at 3.439>1.96. It can be concluded that quality of work life has a direct positive effect on organizational citizenship behavior at $17.6 \%$. The value of construct reliability (composite reliability matrix) and average variance matrix extracted variable quality of work life (X2) and organizational citizenship behavior (Y), where the value of construct reliability (matrix composite reliability) quality of work life is worth $0.942>0.70$, it can be concluded significant and for the average variance extracted quality of work life value of $0.507>0.50$ it can be concluded significant. While the value of construct reliability (composite reliability matrix) organizational citizenship behavior is worth $0.932>0.70$ it can be concluded significant and for the average variance extracted quality of work life value is $0.507>0.50$ it can be concluded significant. The results of this study reinforce the theory put forward by Ghasemi et al. (2016) which shows there is a direct and significant relationship between quality of work life and organizational citizenship behavior (OCB). Subsequent research by Marlinda (2017) shows that there is a very significant positive relationship between the quality of work life and organizational citizenship behavior (OCB). While research by Amalia et al. (2014) shows that of the 9 components of quality of work life there is only 1 variable that is able to influence the level of OCB employees through job satisfaction, namely career development.

\subsection{Effect of job satisfaction on organizational citizenship behavior}

The effect of job satisfaction on organizational citizenship behavior is positive at 0.181 and significant at $2.245>1.96$. Thus, it can be concluded that the quality of work life has a direct positive effect on organizational citizenship behavior by $18.1 \%$. The value of construct reliability (composite reliability matrix) and average variance matrix extracted variable job satisfaction (X3) and organizational citizenship behavior (Y), where the value of construct reliability (composite reliability matrix) job satisfaction is worth $0.919>0.70$ then it can be concluded significant and for the value average variance extracted job satisfaction is $0.511>0.50$ so it can be concluded significant. While the value of construct reliability (composite reliability matrix) organizational citizenship behavior is worth $0.932>0.70$ it can be concluded significant and for the average variance extracted value of job satisfaction is $0.511>0.50$ it can be concluded significant. The results of this study reinforce the theory put forward by Swaminathan \& Jawahar (2013) showing that there is a positive and significant relationship between employee satisfaction with OCB. Furthermore, Prasetio et al. (2015) conducted a research at PLN West Java Indonesia and Banten distribution offices and the results of the job satisfaction research had a significant effect on organizational citizenship behavior (OCB). Subsequent research by Dewi and Suwandana (2016) conducted research on Aget Jaya Hotel employees showing job satisfaction has a positive and significant effect on organizational citizenship behavior (OCB). 


\subsection{Effect of leadership on job satisfaction}

The influence of leadership on positive job satisfaction is 0.465 and significant is $9.219>1.96$. Thus, it can be concluded that leadership has a direct positive effect on job satisfaction by $46.5 \%$. The value of construct reliability (composite reliability matrix) and average variance extracted matrix of leadership variables (X1) and job satisfaction (X2), where the value of construct reliability (composite reliability matrix) of leadership is $0.927>0.70$, it can be concluded significant and for the average variance extracted value leadership value of $0.518>0.50$, it can be concluded significant. While the value of construct reliability (composite reliability matrix) job satisfaction is $0.919>0.70$, it can be concluded that it is significant and for the average variance extracted leadership value is $0.518>0.50$ and it can be concluded significant. The results of this study reinforce the theory put forward by Widodo (2014) showing that leadership has a significant and positive effect on job satisfaction. Furthermore Budiman (2017) in his research found that leadership has a significant effect on job satisfaction. Subsequent research by Susilowati (2014).

\subsection{The effect of quality of work life on job satisfaction}

The influence of quality of work life on positive job satisfaction is 0.413 and significant is $9.370>1.96$. Thus, it can be concluded that the quality of work life has a direct positive effect on job satisfaction by $41.3 \%$. The construct reliability value (composite reliability matrix) and the average variance matrix extracted variable quality of work life (X2) and job satisfaction (X3), where the value of construct reliability (matrix composite reliability) quality of work life is worth $0.942>0.70$ so it can be concluded significant and for the average variance extracted quality of work life is worth $0.507>0.50$ so it can be concluded significant. While the value of construct reliability (composite reliability matrix) job satisfaction is worth $0.919>0.70$, it can be concluded that significant and for the average variance extracted quality of work life value is $0.507>0.50$, it can be concluded significant. The results of this study reinforce the theory put forward by Anbari et al (2014). The results of the study indicate the quality of work life has a significant effect on job satisfaction. Furthermore, Soni and Rawal (2014) found a significant influence on the quality of work life on employee satisfaction. Next Omega (2015), also reports that QWL has a significant effect on employee satisfaction.

\subsection{The influence of leadership on organizational citizenship behavior mediated by job satisfaction}

The influence of leadership on organizational citizenship behavior mediated by job satisfaction is positive with a value of 0.084 and significant at 2.301> 1.96. Thus, it can be concluded that leadership has an indirect effect on organizational citizenship behavior mediated by job satisfaction by $8.4 \%$. The results of this study reinforce the theory put forward by Juniartha (2016) in his research found that the influence of transformational leadership on OCB is indirect, mediated by job satisfaction.

\subsection{The effect of quality of work life on organizational citizenship behavior mediated by job satisfaction}

The influence of quality of work life on organizational citizenship behavior mediated by positive job satisfaction is 0.075 and significant is $1.988>1.96$. Thus, it can be concluded that leadership has an indirect effect on organizational citizenship behavior mediated by job satisfaction by $7.5 \%$. The results of this study reinforce the theory put forward by Oktaviani and Rijanti (2015).

\section{Conclusion}

From the results of the evaluation and discussion described, the following research conclusions are obtained: leadership has a direct positive effect on job satisfaction. Leadership has a direct positive effect on organizational citizenship behavior. Quality of worklife has a direct positive effect on job satisfaction. Quality of worklife has a direct positive effect on organizational citizenship behavior. Leadership has no direct positive effect on organizational citizenship behavior through quality of worklife. Quality of worklife has an indirect positive effect on organizational citizenship behavior through quality of worklife.

\section{References}

Amalia, R. A., Sudirman, I., \& Kadir, H. A. (2014). The influence of quality of work life of job satisfaction and organizational citizenship behavior (OCB) in Hasanuddin University Hospital Employee. Jurnal Ekonomi Universitas Hasanudi, 10(3).

Anbari, Z., Abbasinia, M., Khadem, M., Rahmani, A., Asghari, M., Nezhad, I. A., \& Dehghan, S. F. (2015). Effects of the quality of working life on job satisfaction in an auto parts manufacturing factory. International Journal of Emergency Mental Health, 17(1), 151-155.

Bateman, \& Thomas. (2007). Management: Leading \& Collaborating in a Competitive World. Boston: : McGraw-Hill Irwin.

Budiman, A. (2017). Pengaruh Kepemimpinan dan Iklim Organisasi terhadap Quality of WorkLife serta implikasinya terhadap KepuasanKerja (Studi kasus pada PT. Mediatama Bina kreasi). Jurnal Ekonomi Manajemen, 2(3), 11-23.

Colquitt, J. A., Lepine, J., \& Michael, W. W. (2015). Organizational Behavior: Improving Performance and Commitment in the Workplace (4th ed.). New York: McGraw-Hill Education.

Dewi, N. L. P. Y. A., \& Suwandana, I. G. M. (2016). Pengaruh Kepuasan Kerja Terhadap Organizational Citizenship Behavior (OCB) dengan Komitmen Organisasional sebagai Variabel Mediasi. Jurnal Ekonomi Universitas Udayana, 5(11), $20-27$.

Erdem. (2014). The level of quality of work life to predict work alienation. Educational Sciences: Theory \& Practice, 14(2), 534-544.

George, J. M. dan G. R. J. (2012). Understanding and Managing Organizational Behavior (6 ${ }^{\text {th }}$ ed.). Prentice Hall. 
Ghasemi, Khodizaee, \& Cherakhi. (2016). Analyze the relationship between QWL and organizational citizenship behavior Zabol university. Journal of Global Pharma Technology, 12(8), 387-393.

Griffin, R.W., \& Moorhead, G. (2014). Organizational behavior: managing people and organizations, $11^{\text {th }}$ ed., Australia: South Western.

James, L. G., James, H. D., Ivancevich, \& Konopaske, R. (2012). Organization Behavior, Structure, Processes (14 edition). New York: McGraw-Hill.

Juniartha, I. B. M. (2016). The effect of transformational leadership on organizational citizenship behavior (OCB) with the mediation of followers' trust in leader and job satisfaction. Jurnal Ekonomi Universitas Udayana, 11(6), 70-79.

Kartini, I. (2017). Pengaruh Gaya Kepemimpinan terhadap Organization Citizenship Behaviour (OCB) Di Politeknik LP3I Jakarta Kampus Jakarta Utara. Jurnal Ekonomi, Bisnis, Dan Akuntansi, 1(4).

Kinickiand, A., \& Kreitner, R. (2010). Organizational Behaviour: Key Concepts, Skill and Best Practises. New York: McGraw-Hill.

Kumar, M. M., \& Shah, S. A. (2015). Psychometric Properties of Podsakoff's Organizational Citizenship Behaviour Scale in the Asian Context. The International Journal of Indian Psychology, 3(1), 51-60.

Marlinda, K. T. (2017). Hubungan antara Kualitas Kehidupan Kerja dan Organizational Citizenship Behavior dengan produktivitas karyawan. Jurnal Ekonomi Manajemen, 6(4), 1-13.

Meri Prasetyawati, K. (2015). Pengaruh Quality of workLife terhadap Kepuasan Kerja karyawan di PT. Gemala Kempa Daya. Jurnal Ekonomi Manajemen, 4(4), 70-79.

Oktaviani, D. Z., \& Rijanti, T. (2015). Pengaruh Quality of Work Life dan Modal Psikologi terhadap Organizational Citizenship Behaviour dengan Kepuasan Kerja sebagai mediasi (StudiPadaPegawaiSetdaKabupatenPemalang). Jurnal Aplikasi Manajemen, 9(7), 61-69.

Omega. (2015). Pengaruh Fakto-Faktor Quality of WorkLife Terhadap Kepuasan Karyawan Pt. Pertamina. Journal Ilmu Administrasi Bisnis, 3(2), 443-457.

Podsakoff, MacKenzie, Paine, \& Bachrach. (2000). Organizational citizenship behaviors: A critical review of the theoretical and empirical literature and suggestions for future research. Journal of Management, 26(3), 513-563.

Prasetio, Siregar, \& Luturlean. (2015). The effects of job satisfaction and organizational commitment on organizational citizenship behavior. Jurnal Siasat Bisnis, 19(2), 99-108.

Rahmi, B. M. (2014). Pengaruh Kepemimpinan Transformasional terhadap Terhadap Organizational Citizenship Behaviour dan Komitmen Organisasional dengan Mediasi KepuasanKerja (Studipada Guru Tetap SMA Negeri di Kabupaten Lombok Timur). Jurnal Ekonomi Manajemen, 2(2), 12-21.

Riadi, E. (2018). Statistik SEM Structural Equation Modeling dengan LISREL. Yogyakarta: Penerbit Andi.

Robbins, S. P., \& Judge. (2013). Organizational behavior (15th ed). Boston: Pearson.

Robbins, S. P., \& Timothy. (2014). Organizational Behaviour (16 edition). New Jersey: Pearson Education.

Soni, \& Rawal. (2014). Impact of quality of work life on employee satisfaction in hotel industry. Journal of Business and Management, 16(3), 37-44.

Susilowati, S. B. (2014). Pengaruh Kepemimpinan dan Komitmen Organisasi terhadap Kepuasan Kerja di mediasi Budaya Organisasi. Jurnal Manajemen Universitas Muhamadiah Surakarta, 2(3), 22-31.

Swaminathan, \& Jawahar. (2013). Job satisfaction as a predictor of organizational citizenship behavior: An empirical study. Global Journal of Business Research, 7(1), 1-10.

Widodo, D. S. (2014). Influence of leadership and work environment to job satisfaction and impact to employee performance. IISTE, 12(4), 31-42.

Yang, Q., \& Wei, H. (2018). The impact of ethical leadership on organizational citizenship behavior: The moderating role of workplace ostracism. Leadership \& Organization Development Journal, 39(1), 100-113.

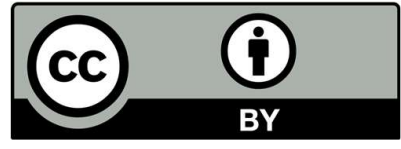

(C) 2020 by the authors; licensee Growing Science, Canada. This is an open access article distributed under the terms and conditions of the Creative Commons Attribution (CC-BY) license (http://creativecommons.org/licenses/by/4.0/). 